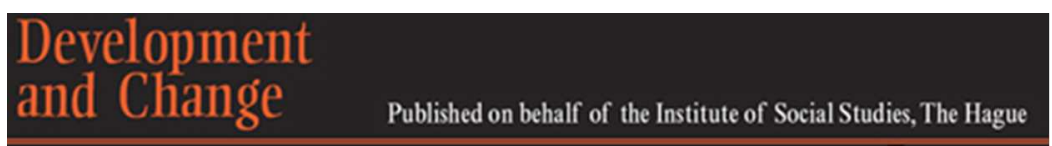

\title{
'Mapping' Small-Scale Mineral Production Networks: The Case of Alluvial Diamonds in Ghana
}

\begin{tabular}{|c|l|}
\hline Journal: & Development and Change \\
\hline Manuscript ID & DECH-16-277.R1 \\
\hline Manuscript Type: & Original Article \\
\hline Keywords: & $\begin{array}{l}\text { artisanal and small-scale mining (ASM), diamonds, Global Production } \\
\text { Network (GPN), Ghana, Global Value Chain (GVC) }\end{array}$ \\
\hline & $\begin{array}{l}\text { In recent years, donors and certain governments have committed to } \\
\text { formalizing and supporting artisanal and small-scale mining (ASM)-low- } \\
\text { tech, labour-intensive mineral extraction and processing. Few, however, } \\
\text { are able to do so effectively because of a limited knowledge of how the } \\
\text { sector operates, who it employs and where the commodities it mines are } \\
\text { being channelled. This article argues that a radical re-conceptualization of } \\
\text { ASM will be needed if these challenges are to be overcome. As a starting } \\
\text { point, it calls on donors and policymakers to adopt the Global Production } \\
\text { Network (GPN) as a 'lens' for analyzing the sector's organizational } \\
\text { structures. Popular in geography scholarship, the GPN, though rarely used } \\
\text { to study the intricacies of largely-informal sectors such as ASM, could } \\
\text { prove valuable here, aiding with the mapping of key production } \\
\text { processes. The GPN was applied to Ghana's artisanal diamond mining } \\
\text { sector, research which yielded valuable insight about its organization, the } \\
\text { roles played by the different individuals who populate it, and the nature of } \\
\text { the relationships between these individuals. This information is a key to } \\
\text { designing more robust formalization and support strategies for ASM in the } \\
\text { country, and the exercise, overall, provides important lessons for other } \\
\text { governments working to achieve similar goals. }\end{array}$ \\
\hline
\end{tabular}




\begin{abstract}
In recent years, donors and certain governments have committed to formalizing artisanal and small-scale mining (ASM)-low-tech, labour-intensive mineral extraction and processing. Few, however, are able to do so effectively because of a limited knowledge of how the sector operates, who it employs and where the commodities it mines are being channelled. This article argues that a radical re-conceptualization of ASM will be needed if these challenges are to be overcome. As a starting point, it calls on donors and policymakers to adopt the Global Production Network (GPN) as a 'lens' for analyzing the sector's organizational structures. Popular in geography scholarship, the GPN, though rarely used to study the intricacies of largely-informal sectors such as ASM, could prove valuable here, aiding with the mapping of key production processes. The GPN was applied to Ghana's artisanal diamond mining sector, research which yielded valuable insight about its organization, the roles played by the different individuals who populate it, and the nature of the relationships between these individuals. This information is a key to designing more robust formalization and support strategies for ASM in the country, and the exercise, overall, provides important lessons for other governments working to achieve similar goals.
\end{abstract}

Keywords: Global Production Network (GPN); Artisanal and Small-Scale Mining (ASM); Diamonds; Global Value Chain (GVC); Ghana 


\section{INTRODUCTION}

Few topics have polarized the international development community more so than artisanal and small-scale mining (ASM) - low-tech, labour-intensive mineral processing and extraction (Hentschel et al., 2002; Hilson et al., 2014). Long treated in policy as an economic activity populated by enterprising businessmen and rogue entrepreneurs, ASM has finally caught the attention of several donors and NGO officials. In response to mounting evidence which points to the sector being largely poverty-driven (Barry, 1996; Hilson, 2012), having inseparable ties with agriculture (Kamlongera, 2011; Maconachie, 2011; Maconachie and Binns, 2007), becoming one of the most important rural nonfarm activities in sub-Saharan Africa and other areas of the developing world (Hilson, 2010; Hilson, 2016), and in numerous impoverished environments, serving as a platform for wealth-creation (Hilson and Garforth, 2013; Werthmann, 2009), these actors have called for the implementation of comprehensive policies and programs that support its activities.

The impact of the work undertaken thus far to achieve this, however, has been negligible. With most ASM being firmly rooted in the informal economy, donors and host governments have, predictably, struggled to create 'space' for the sector in a development apparatus that has evolved without much recognition of its growing importance. As captured by a collection of recently-published scholarly works (e.g. Fisher, 2007; Banchirigah, 2008; Van Bockstael, 2014; Verbrugge, 2015), contemporary ASM economies are comprised of a number of highly-organized, and at times, interlocking, activities; are populated by an array of actors, including diggers, machine owners and buyers; feature complex labour hierarchies; and 'feed' equally-dynamic supply chains and networks. The reluctance of decision-makers to abandon their antiquated views of ASM, perceptions which have kept the sector on the periphery of international development debates for decades, along with their unfounded confidence in a formalization strategy that emphasizes a 'stick and carrot' approach to licensing, has spawned inappropriate interventions and policies that have failed to bring activities into the legal domain. The need for more operator-friendly ASM formalization and support strategies has never been more apparent.

This article helps to address this concern by providing a broader conceptualization of the complexities of ASM networks and the relationships forged between the key actors who populate them. It is this crucial information which donors and government officials lack but will require if they are to design more appropriate policies, support services and formalization 
strategies for the sector. The article argues that the Global Production Network (GPN), defined as 'the globally organised nexus of interconnected functions and operations by firms and non-firm institutions through which goods and services are produced and distributed' (Coe et al., 2004: 471), could provide much-needed guidance on this front. Although never used as a 'lens' to retrieve information about the organizational complexities of a largelyinformal sector such as ASM, the GPN is recognized as a dynamic framework capable of unearthing details about how networks operate. Moreover, as Hughes et al. (2008: 348) explain, the GPN 'prioritize[s] social processes and interaction[s] between agents comprising [these] network dynamics', a detailed knowledge of which could help broaden understanding of how and why industries such as ASM proliferate in informal 'spaces'. Strangely, although the GPN framework has been praised for its ability to facilitate the collection of information across and at all levels of a nexus, to date, its application has been rather conservative. It has been used mostly to retrace and capture additional data about supply chains that are vertically-integrated and/or for which there is already an abundance of information available. But whilst empirical research on the GPN has yet to live up to the hype surrounding its utility, as a tool for understanding and analyzing the dynamics of complex and largelyinformal industries such as ASM, its value could be enormous.

The article begins by critiquing the GPN, as well as discussing further its potential utility as a framework for mapping informal ASM activities and making sense of the relationships forged between its key constituents. Next, the article uses the GPN framework to develop a more nuanced understanding of the dynamics of Akwatia, Ghana's artisanal diamond mining hub. The analysis yields a detailed picture of the network of actors who populate this town's ASM operations, and, focusing on a cross-section of the 'level' they are a part of, illustrates how the intricate relationships forged between certain actors drives activities, and affects the movement of finance and stones at the lower echelons of the supply chain for alluvial diamonds in Ghana. The article concludes by reflecting critically on how the information retrieved using the GPN framework could lead to the design of more appropriate formalization strategies and robust support services for alluvial diamond mining, and the ASM sector more broadly. 


\section{APPLYING THE GPN FRAMEWORK TO ARTISANAL AND SMALL-SCALE MINING}

Although a detailed history of commodity chain scholarship is beyond the scope of this paper, some coverage of its antecedents is necessary, as it helps to frame the case study of Akwatia that follows. A logical starting point is the work of Gereffi (1994, 1999, 2005), who is credited with having initially advanced Hopkins and Wallerstein's (1986) pioneering analysis of 'commodity chains' (Gereffi et al., 2005; Bernstein and Campling, 2006). The author very importantly drew attention to 'the commercial dynamics between firms in different segments of the production chain' at a time when the investment presence of multinational corporations was becoming very visible across the developing world. The author's seminal Global Value Chain (GVC) framework continues to have enormous application today, as does his useful typology of producer-driven and buyer-driven chains.

The limitations of the GVC framework in explaining the dynamics of a globalizing world, however, sparked the launch of the GPN. This 'broad relational framework', its champions principally, those closely associated with the so-called 'Manchester school' of economic geographers (Yeung and Coe, 2015) - contest, 'go[es] beyond the very valuable but, in practice, more restricted, global commodity chain (GCC) and global value chain (GVC) formulations' (Coe et al., 2008: 272) by 'captur[ing] the multi-stranded connections between producers, traders, retailers and consumers' (Hughes et al., 2008: 4). The GPN's chief distinguishing attribute is an emphasis on horizontal relationships, or 'The institutional environment and agents not directly involved in production or commercialization [who] might play a key role in setting the conditions for production and trade' (Muradian et al., 2011: 270). Coe et al. (2008: 274-275) shed greater light on the importance of taking into account these horizontal relationships in commodity chain analysis:

In a production network, whose 'purpose' is to create value through the transformation of material and non-material inputs into demanded goods and services, there is inevitably an element of linearity or verticality in the structure of its nodes and links...This captures the process of sequential transformation from inputs, through stages of transformation to outputs and through to distribution and final consumption, a sequence in which each stage adds value to the process of production of goods or services...However, focusing only on the linear/vertical dimension of a production 
network is undoubtedly a problem... Such multi-dimensionality must be incorporated in any analysis of production networks without, at the same time, losing sight of the 'directed' nature of the processes involved.

After collating literature which casts light on the organizational structures of the informal ASM economies that have proliferated across the developing world (see e.g. Banchirigah, 2008; Fisher, 2007; Verbrugge, 2015), it becomes very clear that operators' relationships with major actors who are 'not directly involved in production or commercialization', including landowners, traditional leaders and particular sponsors, are indeed shaping the commodity chains they are a part of. Proponents of the GPN framework would argue that 'such relationships determine how much value is created, enhanced, and captured at each node' (Murphy, 2012: 210).

Can this 'broad relational framework', however, help to facilitate the collection of detailed data on the informal industries now rooted across the developing world, including dynamic activities such as ASM? Certainly, the impetus behind the GPN's skilful promotion as a framework which yields a more nuanced understanding of globalizing industries and the increasingly-complex networks they have become a part of in an interconnected world would suggest this to be the case. A common feature of the main industries examined in the GPN literature to date is that a large share of their production takes place in developing countries. But at the same time, this burgeoning body of work contains limited - and, when considering the hype surrounding the framework's utility, disappointing - analysis of this production. It draws sweeping conclusions from a very limited pool of findings, retrieved mostly from topdown analysis of supply chains linked to selected apparel, foodstuffs, flowers and electronics (e.g. Barrientos, 2013; Brooks, 2013; Raj-Reichert, 2013), for which substantial information about 'sourcing' already exists. There is even less analysis on the role played by the informal economy in GPNs, an omission which few scholars other than Phillips (2011) have comprehensively acknowledged. This is significant because, as is pointed out by the author, 'informalization has been seen as particularly pronounced in parts of the world that might be described as "emerging" or "developing", at least in terms of the numbers of people it encompasses' (p. 381). Perhaps it is a case of the main industries profiled in the GPN literature not lending themselves to such an investigation. Nevertheless, in other contexts where sizable informal industries such as ASM intersect, or in many cases, feed, global supply chains, this is a major oversight. 
Under the direction of the 'Manchester school', the GPN literature has become overlypreoccupied with further discrediting the GVC (Coe et al., 2008; Coe and Hess, 2013; Yeung and Coe, 2015); expended considerable energy re-conceptualizing, revisiting and repackaging the same ideas, mostly through self-citation; and spent more time producing glossaries and typologies of this 'broad relational framework' - two recent examples being 'GPN 2.0' (Yeung and Coe, 2014) and 'Global Production Networks A-Z' (Coe, 2011) - than actually enriching a limited empirical foundation. The former is particularly perplexing: is it productive and even appropriate to condemn the GVC for 'not doing enough' more than two decades after its inception, and at a time when globalization has taken on many different and unpredictable dimensions? It is more inexplicable when considering that even Gereffi (2005) himself, recognizing the limitations of the initial GVC in a rapidly-globalizing world, minted a new typology in an effort to modernize the framework. The author has furthermore acknowledged the utility of the GPN, particularly its ability to put researchers in a position to capture the fine details of governance and institutional structures, and has called for dialogue to be initiated between its chief proponents and scholars promoting the GVC framework. He correctly observed that 'They do not cite one another's research or engage in collaborative projects, despite the fact that both are concerned with the international forces shaping countries and firms in the global economy' (p. 170).

Ironically, the GPN's most significant contribution could be as a framework for assisting with the mapping of industrial networks its champions seem to be avoiding. Heading the list is the extractive industries, which, as Bridge (2008: 389) pointed out nearly a decade ago, 'have not been central to the Global Commodity Chain (GCC), Global Value Chain (GVC) or Global Production Network (GPN) intellectual projects'. In fact, since Bridge's (2008) comprehensive analysis of the global oil economy, only a small collection of GPN studies on extractives - notably, Dicken's (2011) description of the oil and copper sectors, Radhuber's (2015) conceptualization of flows in mining and hydrocarbon extraction, and dos Santos and Milanez's (2015) very informative analysis of iron ore production in Brazil - have emerged. This is a surprising development, given the highly-internationalized state of mining, and oil and gas production and their networks, which make them ideal cases for investigation. What is unsurprising, however, is that no attempt has been made to apply the GPN framework to ASM. The issue is, once again, the lack of analysis in the literature about the role played by the informal economy in GPNs, and very little commitment by researchers to retrieve such information (after Phillips, 2011). 
Despite suggestions that the latest iteration of the GVC remains 'a set of ideal-types based upon quite a narrow (deliberately so) view of production networks' (Coe et al., 2008: 275276), both it and the way in which the GPN framework have been projected are equally restrictive in their focus, fixated mostly on firm and sector-level activities. The rhetoric of the 'Manchester school' suggests, once again, that proponents of the GPN recognize this, the most recent indication being calls for 'GPN 2.0' to encapsulate a move away from 'generalizations at the sectoral level' towards an 'actor centered perspective' (Coe, 2015). But despite such bold assertions, designers seem unable to move beyond the idea of networks revolving around a lead firm, so much so that in their re-conceptualization of 'GPN 2.0', they define a GPN as 'an organizational arrangement comprising interconnected economic and noneconomic actors coordinated by a global lead firm and producing goods or services across multiple geographic locations for worldwide markets' (Yeung and Coe, 2014: 32). Adopting this approach in the extractive industries, however, is bound to lead to the exclusion of a substantial share of activities: whilst in the four studies mentioned above, each of which focuses on large-scale production, there are lead firms, for ASM, there are no dominant players among the many millions of operators scattered across the developing world. Moreover, and reinforcing Phillips' (2011) claim that 'The structural integration of informality in GPNs, and the blending of informality and formality, is easily grasped by exploring the dynamics of the global productive economy', a considerable share of global mineral output originates from a mixture of informal and licensed (or semi-formal) ASM activities.

Building on points raised by Phillips (2011), the analysis that follows marks the first attempt made to apply the GPN framework to ASM, despite it being perhaps the oldest, and most embedded, example of a truly global production network (Hilson, 2006; Cleaveland, 2014). Although the development agenda has become more receptive to formalizing and assisting ASM, donors and host governments have struggled to design appropriate support services and licensing schemes for the sector's participants, a large percentage of whom work in precarious conditions. In sub-Saharan Africa, where most individuals engaged in ASM operate without a license, formalization promises to be particularly challenging. Detailed explanations for why this informality persists is beyond the scope of this paper but in short, the evidence points to it being largely 'created' by bureaucratic policies and regulations (Hilson, 2013; Hilson et al., 2014; ILO, 1999). This is a direct result of host governments favouring a blueprint of large-scale mine development (Hilson, 2017), and, as experiences 
with diamonds in the Central African Republic (Levin and Hinton, 2010), Guinea (Freudenberger, 2012), Liberia (Van Bockstael, 2014) and Côte d'Ivoire (Dejong, 2013), and gold in Zimbabwe (Spiegel, 2015) and even Ghana (Hilson and Potter, 2005) reveal, permits being extremely costly and difficult to obtain, this being due to the licensing procedure designed with the opportunistic entrepreneur armed with finance in mind, as opposed to individuals who are struggling economically.

If, however, 'Harnessing the potential of small scale mining to improve livelihoods and integration into the rural and national economy' is, indeed, a primary goal of the Africa Mining Vision, ${ }^{1}$ donors, host governments and NGOs must respond comprehensively to calls made repeatedly over the years (Davidson, 1993; Hentschel et al., 2002; ILO, 1999) to simplify licensing schemes and 'block out' areas for licensed operators to work. This would require a collective commitment on the part of these actors to developing a more nuanced understanding of how the ASM activities which proliferate across the region function; who populates the communities where production takes place; and the nature of the relationships between different actors in the sector and how they influence day-to-day operations. The GPN framework could provide valuable guidance in these areas, in particular, direction on 'how to act' by uncovering details about the dynamics of the relationships forged between the sector's actors.

The series of donor, industry and NGO reports produced to date (e.g. RJC, 2014, HRW, 2015; World Bank, 2011) which attempt to do this fail to inspire, depicting transactions very linearly. Most barely acknowledge the very significant roles played by local-level actors, and the organization of the informal spaces many are a part of. Although comprehensive in their own right, the scores of country reports commissioned over the past decade also fail to bridge these sizable gaps in knowledge. They tend to focus on exceptional cases such as Ethiopia (CRC Sogema, 2014), where ASM supply chains are unique, flourishing and becoming the mainstay of an extractives economy where, at the time of writing, there was only one largescale mine operator (Midroc), and Guyana, a rare example of a country where the entire

\footnotetext{
${ }^{1}$ As stated on its website, the African Mining Vision, which was formally adopted in February 2009, is a pathway, conceived by African nations, which puts the 'continent's long term and broad development objectives at the heart of all policy making concerned with mineral extraction'. It sets out a blueprint which, in the eyes of the continent's politicians, 'can be used to drive continental development'. ('Africa Mining Vision', 2016).
} 
mining sector has, until recently, been populated exclusively by indigenous small-scale operators (Da Silva-Glasgow, 2013).

The discussion that follows steers away from the - at times, convoluted - analysis that has emerged over the past two decades on the GPN. It returns to the core principles of value, power and embeddedness on which initial conceptualizations of the GPN were based (Henderson et al., 2002: 358), producing an analysis rooted in the framework's initial goal of improving the 'human condition in [an] age of economic and geo-political turbulence'. These elements are each divided further into value creation (processes of labour and economic rents), value enhancement (through technology and value-add activities) and value capture (determined by policy, ownership, and employer rights); corporate power (wielded by the firm or company), institutional power (international, national, and local governance arrangements) and collective power (agents of change such as trade unions, NGOs, and associations); and finally, territorial embeddedness (the influence of a firm on the particular location) and network embeddedness (the structure of the GPN and connections between the different firms and/or actors within and in relation to it).

The discussion also places close emphasis on the horizontal, one of few messages the 'Manchester school' has consistently and coherently emphasized over the years. Building on points raised earlier, the GPN is a radical departure from the linear and vertical, which proponents believe to be a significant weakness inherent with unidirectional chain approaches such as the GVC. It rather seeks to capture the details of and more accurately define the multi-directional diagonal linkages that comprise an industry, with a view to developing a more nuanced understanding of its complex processes of production. Research on livelihoods (Fisher, 2007; Hilson and Garforth, 2013) has shown that the nodes and networks in which ASM is found are, indeed, intricate interconnected horizontal and vertical linkages that are a part of multi-dimensional and multi-layered lattices of economic and social activity. If, as the AMV implies, the goal is to make ASM more of a centerpiece of African development, governments and donors must study the dynamics of the informal spaces which they have created, and the relationships between the actors who populate them. The section that follows uses the GPN framework to map these intricacies, in the process highlighting the scale of the ASM formalization challenge which looms large. 


\section{MAPPING INFORMAL ASM ECONOMIES IN SUB-SAHARAN AFRICA: THE CASE OF AKWATIA, GHANA}

A detailed mapping of ASM is an essential starting point for donors and government officials interested in formalizing and supporting the sector but who do not have the requisite data on hand to make informed decisions. Retrieving this information about alluvial diamond mining is doubly important, as it could go a long way toward strengthening a Kimberley Process Certification Scheme (KPCS) ${ }^{2}$ which has had very little impact in stemming the smuggling of rough stones between countries with porous borders. As Ghana's proven diamond reserves are mostly confined to Akwatia and surrounding areas, the fulfillment of its KPCS commitments have been relatively straightforward. In March 2008, the Government of Government began registering artisanal diamond miners, equipping each which a mining registration card that is valid for five years (Chirico et al., 2010). At this point, however, a comparative exercise in the likes of Guinea, Sierra Leone or Liberia, where alluvial stones are far more widespread than Ghana (see e.g. Levin and Gberie, 2006; Pijpers, 2014; D'Angelo, 2015; Engwicht, 2016), would be a challenging, if not, impossible undertaking. But if formalization of ASM is to be a centerpiece of the African development agenda moving forward, in addition to licensing schemes and support services needing to be more in tune with the capabilities and needs of operators, broader, complementary initiatives such as the KPCS must be strengthened. The following mapping exercise illuminates on the type of information that can solidify the bedrock for formalizing and supporting ASM in sub-Saharan Africa.

The analysis provides a more nuanced understanding of what is referred to here as the 'artisanal production strand' of the GPN for diamonds. This should not be confused with its 'large-scale production strand', a space populated by the likes of diamond giant De Beers and

\footnotetext{
${ }^{2}$ The Kimberley Process Certification Scheme (KPCS) is a joint government, civil society, and industry initiative aimed at stemming the flow of rough diamonds used to finance wars. It was 'officially' launched in 2003 (Table 1).
} 
other companies such as BHP Billiton which have capital-intensive operations. ${ }^{3}$ Informed by experiences from a preliminary visit in 2009, research was carried out in Akwatia as part of a 12-month project on ASM in Ghana (in 2014-2015). Following an initial mapping of the sector (Figure 1), its main actors were interviewed, with a view to developing an improved understanding of the organization of operations and the types of relationships key players have with one another. In total, 50 stakeholders in Akwatia and surrounding areas, central to the functioning of local diamond production, were interviewed, including tributers, assembly members, local chiefs, sponsors, diamond dealers, labourers, miners, equipment makers and renters, and officials from the resident large-scale mining company, Great Consolidated Diamonds Ltd. (GCDL). These local stakeholders were identified, approached and interviewed through snowball sampling and the support of a fieldwork assistant who also resides in Akwatia. Ten additional interviews were carried out with national and international stakeholders, principally those who make up the governance structure for alluvial diamonds in Ghana, including the Precious Minerals and Marketing Company (PMMC), and licensed buying companies located in its office; various chiefs, who are empowered by law to collect and disburse surface rents; and officers at the Minerals Commission, which falls under the Ministry of Lands and Natural Resources, and is the main regulatory body for mining in Ghana (Table 1). This section of the paper draws on these findings.

Table 1: Agencies Regulating Diamond Production in Ghana

\begin{tabular}{|c|c|}
\hline Institution & Role and responsibility \\
\hline $\begin{array}{l}\text { Kimberley Process } \\
\text { Certification Scheme }\end{array}$ & $\begin{array}{l}\text { A joint government initiative established in } 2000 \text { to stop the trade of so called 'conflict diamonds'; rough stones used to } \\
\text { finance rebel movements and wars. Member states must meet minimum requirements and enact legislation and institutions } \\
\text { concerning export, import and internal controls, commit to transparency and the publishing of statistical data. Between } \\
\text { November } 2006 \text { and March } 2007 \text {, the Kimberley Process suspended the export of diamonds from Ghana for fears over } \\
\text { conflict diamonds entering the Ghanaian supply chain from Côte d'Ivoire. }\end{array}$ \\
\hline Minerals Commission & $\begin{array}{l}\text { The main promotional and regulatory body for the minerals sector in Ghana responsible for regulating and managing } \\
\text { mineral resources, and coordinating and implementing mining-related policies. Operates nine district ASM offices that } \\
\text { support current and prospective small-scale miners. There is no office in Akwatia. }\end{array}$ \\
\hline $\begin{array}{l}\text { Precious Minerals } \\
\text { Marketing Corporation }\end{array}$ & $\begin{array}{l}\text { A limited company, of which the Government of Ghana is the majority shareholder, charged with managing the purchase, } \\
\text { export and marketing of Ghana's diamonds (and gold). PMMC licenses the sale and export of diamonds through the } \\
\text { issuing of licenses to international buying companies, and two tiers of local buying licenses (Table 2). On request of } \\
\text { international diamond buying companies in Accra, PMMC processes export to a pre-determined oversees address by } \\
\text { completing the Bank of Ghana and Ghana Customs forms, sealing the parcels, adding the Kimberley certification } \\
\text { documents, and delivering to the export airline (KLM) at Kotoka International Airport, Accra. An export fee of } 2.3 \text { per } \\
\text { cent per parcel is charged. }\end{array}$ \\
\hline $\begin{array}{l}\text { Great Consolidated } \\
\text { Diamonds Limited }\end{array}$ & $\begin{array}{l}\text { The private Ghanaian company that has owned the mining concession encompassing Akwatia since } 2011 \text {, acquiring it } \\
\text { from the parastatal, Ghana Consolidated Diamonds Ltd. (GCD), and licenses tributers to mine on its concession. Small- } \\
\text { scale miners must meet certain conditions and sign the 'Tributer Mining Contract' stipulating that all diamonds mined } \\
\text { should be presented to the GCDL. }\end{array}$ \\
\hline Denkyembour District & One of 26 administrative districts in Ghana's Eastern Region, that was carved out of the Kwaebibirem District and \\
\hline
\end{tabular}

${ }^{3}$ Those mining at the artisanal level are working alluvial deposits. Most large-scale diamond mine operators work kimberlite deposits but some also harvest stones that occur alluvially. Here, the 'artisanal production strand' is defined as the actors and organizational structures comprising the segment of the chain mining alluvial diamonds on an artisanal scale. 


\begin{tabular}{|l|l|}
\hline Assembly & $\begin{array}{l}\text { established in February } 2012 \text { with Akwatia as its capital. District assemblies hold administrative and legislative power and } \\
\text { are responsible for the development and administration of the areas they govern. }\end{array}$ \\
\hline $\begin{array}{l}\text { Office of the Administrator } \\
\text { of Stool Lands }\end{array}$ & $\begin{array}{l}\text { Responsible for the collection and disbursement of stool land (held in customary ownership by the relevant traditional } \\
\text { authority i.e. chiefs) revenue. This includes revenues from mining activities on the land. }\end{array}$ \\
\hline
\end{tabular}

Sources: Ghana Government, 2016; KPC, 2016; Mahama and Baffour, 2009; MLNR, 2016; MinCom, 2016; Nyaungwa, 2016; PMMC, 2016 


\section{The Global Diamond Supply Chain in Context}

When grafted on to the GPN for diamonds and the 'artisanal production strand' for West Africa, Akwatia occupies a small segment. Whilst precise data are unavailable, there is reason to believe, based on levels of declared production alone, that there are hundreds of thousands of artisanal diamond miners scattered across West Africa in countries such as Liberia, Sierra Leone, Côte d'Ivoire and Guinea. Ghana has, by comparison, only a fraction of the number of diggers found in these countries, all of whom are based in and around Akwatia, where almost all the country's proven diamond reserves are found: according to the most recent statistics, there are 6420 diamond workers and tributers registered in the government's Mining Registration Database (Chirico et al., 2010). This figure could be even lower today, given Ghana's fast-depleting reserves of accessible alluvial stones, and the growing popularity of small-scale gold mining as an alternative livelihood (Hilson, 2010; Hilson and Garforth, 2013).

But despite Akwatia's small, and diminishing, level of diamond production, analysis of its organizational structures could yield valuable insight into the complexities and intricacies of, and relationships between the millions of actors who today populate, the world's alluvial diamond sector, which produces 10 to 15 per cent of the world's rough stones. Alluvial diamonds, most of which originate from sub-Saharan Africa, flow to points of export in local respective supply chains. At various points within the distribution, cutting and polishing sections of the GPN for diamonds, these supply chains fuse with those linked to the 'largescale production strand', which is tied to operations working the kimberlite pipes of Southern Africa. A brief overview of the upstream sections of the GPN for diamonds, along with the industry's key historical developments, helps to put the case of Akwatia into context.

The alluvial diamonds being mined in Ghana and elsewhere in sub-Saharan Africa are a part of a unique GPN long manipulated and controlled by the corporate giant De Beers. As detailed in a series of informative reports (e.g. Hiraway, 2009; Bain and Company, 2011), from its upstream position, the company, through a complex network of subsidiaries, had skillfully used the distribution and marketing channels for rough stones to control downstream activities in the diamond value chain. De Beers no longer has absolute monopolistic control of the diamond trade it once had. But its protracted stranglehold over the marketing and supply of rough stones has shaped, and continues to influence - both directly and indirectly - the foundation for global diamond production, an intricate network 
of nodes and linkages into which a burgeoning group of alluvial miners scattered across subSaharan Africa are now an integral part of.

On the back of what is widely regarded as one of the most successful advertising campaigns in history, De Beers' skillful marketing in the late-1950s fueled an unprecedented increase in demand for small high-quality diamonds which European cutters and polishers at the time could not satisfy. This would trigger, in the 1970s, a sharp rise in the number of diamond workshops in India, where production costs were considerably lower. India has since become the world's most important diamond cutting and polishing centre due to its continued low production costs (approximately ten per cent the cost of that in the United States, for example); it having a workforce comprised of numerous specializations and skills, capable of working all 7000 types of the world's diamonds; and very importantly, given how most diamonds lose fifty to sixty per cent of their weight because material is removed from the rough product, there being a number of cutters and polishers who have considerable experience handling small, low-value stones (Bain and Company, 2011; Engleshoven, 1999; Hiraway, 2009; Purani and Mehta, 2000). Whilst Antwerp, which has more than five centuries of history as a centre for cutting, polishing and trading, continues to be the world's major diamond hub, through which 80 per cent of global rough volume is traded and subsequently sorted and then dispatched to cutters and polishers around the world, during the past 50 years, India has cemented its place, and now occupies an indispensable position, in the GPN cultivated by De Beers. Substantial quantities of alluvial stones find their way to scores of diamond workshops in India, mostly in the state of Gujarat, in particular the town of Surat, because of its proximity to the 30-40 sightholders ${ }^{4}$ based in Mumbai, as well as localities such as Ahmedabad, Baroda, Visnagar, Mehsana, Sidhpur, Palanpur and Saurashtra (Purani and Mehta, 2000).

Figure 1: Ghana interlocking with the GPN for diamonds

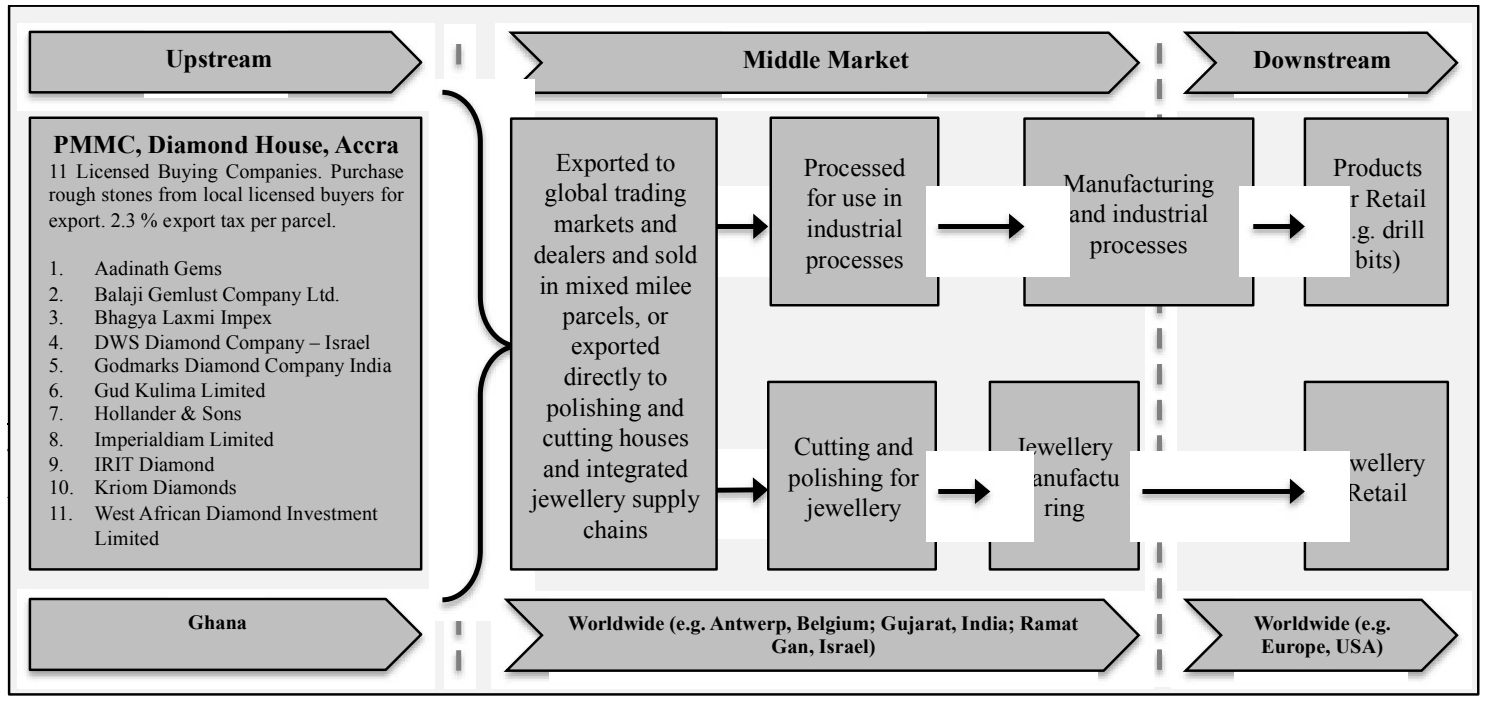


The diggers who extract these stones, and the local networks they are a part of, have been the focus of considerable debate in donor, policymaking and NGO circles in recent years (Global Witness, 2006; PAC, 2008; Van Bockstael, 2014). Most operate at a subsistence level; struggle mightily to accumulate wealth; at times, become trapped in exploitative labour structures; and tend to rely heavily on the relationships they forge with a host of other locallevel actors for their survival. With a policy debate focused squarely on ASM formalization, now would seem to be the opportune time to 'reach', and subsequently empower, these individuals. Can the livelihoods of these diggers and others who occupy the lower rungs of the alluvial diamond mining sector in sub-Saharan Africa be improved, and, in line with the objectives of the KPCS, the traceability of the rough stones they extract be guaranteed? This will require a more nuanced understanding of the networks they comprise and the working relationships they have forged, which a detailed analysis of Akwatia has helped to uncover. Such information could go a long way toward empowering diggers in Ghana and elsewhere in sub-Saharan Africa.

\section{Embeddedness}

Unlike conventional GPN studies, this analysis begins with 'embeddedness'. With some understanding of the factors that have shaped diamond production in Akwatia, the dynamics of the town's power structures and networks become clearer. As a result, 'value' and 'power' can be better articulated.

As explained, in the traditional GPN framework, embeddedness can take two forms (Henderson et al., 2002: 252), although neither is explained very clearly. The first, territorial, relates to the 'anchoring' of a GPN's firms in different places, which 'affects the prospects for development in these locations'. For example, a lead firm's commitment to a geographical location can mobilize clusters of local businesses. It may also entice the host government to overhaul taxation and labour policies with the aim of 'embedding' a portion of the GPN. These moves ultimately create value.

But it is the second, network, which resonates more powerfully here. This type of embeddedness relates to the 'network structure, the degree of connectivity within a GPN, the stability of its agents' relationships and the importance of the network for the participants', an analysis of which helps to cast light on the horizontal dimension. Significantly, however, 
with the foundational work premised upon there being a 'lead firm' around which a GPN develops - a point which will be repeatedly revisited throughout this analysis - some clarification is required. The story for complex extractive industries such as ASM is very different.

On the one hand, in Ghana, alluvial diamond mining activities and their networks have, in line with the GPN literature, emerged and further evolved under the influence of a lead firm: in this case, Ghana Consolidated Diamonds Ltd. (GCD) and its predecessor, the Consolidated African Selection Trust (CAST). ${ }^{5}$ For over 100 years, Akwatia, with its potholed roads, poor infrastructure and a population (as of 2010) of approximately 22,000 people (Ghana Statistical Service, 2014: 70), has been embedded at the base of the GPN for alluvial diamonds. The first discoveries were made in 1919 when Ghana was the Gold Coast Colony, under the control of the British. The Birim deposit has yielded 90 per cent of the rough stones mined in Ghana to date, and remains the centrepiece of its diamond production (Greenhalgh, 1985; Chirico et al., 2010). Today, most of the stones extracted in and around Akwatia are characteristically small: ${ }^{6} 35-45$ per cent are poor gemstone quality, referred to as boart, and sold for use in industrial processes (cutting, grinding, drilling, polishing). But by total volume, Ghana has produced the most diamonds in West Africa to date; between 1920 and 2014, 115 million $^{7}$ carats were recovered from its soils (Janse, 2007; KPC, 2016).

The labour networks found in Akwatia today are deeply rooted. Their foundations, along with the town's cultural and social fabric, have been shaped heavily by both companies. Active recruitment by CAST and voluntary migration, fuelled by the thousands of miles of 'feeder' roads and railway lines laid by the Gold Coast Government, would fuel a rapid influx of people to Akwatia in the 1930s and 1940s (Greenhalgh, 1985). Employees of CAST's Akwatia Mine were provided with housing, supplied with pipeborne water and free healthcare at the company hospital, the opportunity to purchase subsidized foods from the

\footnotetext{
${ }^{5}$ Following the discovery of diamonds in Akwatia, several companies began mining along the Birim River. In 1924, the most significant, the British-owned Consolidated African Selection Trust (CAST), was established. It was very successful, with exports valued at $£ 460,000$ between 1925 and 1929 , capitalizing on its monopolistic position on diamond mining in Ghana as well as other colonies, notably Sierra Leone (Greenhalgh, 1985).

${ }^{6}$ Ghana's diamonds are known for their small size. These melee stones ( 0.001 up to 0.15 carats / $0.6 \mathrm{~mm}$ to $3.5 \mathrm{~mm}$ ) trade hands regularly in mixed parcels at international markets, and depending on quality, are used in jewellery making and industrial processes (Chirico et al., 2010; Morbiwala, 2015). ${ }^{7}$ Calculations based on data from: Chirico et al., (2010); KPC (2016); PMMC (2016).
} 
company's coldstores, and a chance to compete for scholarships for their children's educations. Thousands of others migrated to Akwatia, lured by the company's activities, whilst scores of local rural families soon found themselves supplying and trading in the town's swelling markets. Most of Akwatia's residents today are descendants of this eclectic group of migrants and locals (Cleaveland, 2014; Greenhalgh, 1985).

On the other hand, and a slight departure from the GPN literature, it was the deterioration, not the success, of the Akwatia Mine, following its hostile takeover by GCD in the early-1980s, that would galvanize and embed the town's alluvial diamond economy, fortifying its networks and clusters of ancillary industries. Output from the company, which failed to overhaul its obsolete production facilities, declined rapidly, forcing management to lay off several hundreds of its staff, most of them carryovers from CAST. As one company official, reflecting on the impact of this retrenchment, explained in an interview, 'the future of mining, it's going down ... many workers have been laid off, so the town is almost a ghost town ... That wasn't the case [before 2007]'. ${ }^{8}$ Frustrations over not benefitting from diamond mining rapidly mounted in the community where, reportedly, the streets once glistened with stones after heavy rains, and where people have more recently dug up floors and knocked down the plastered mud brick walls of old buildings to sieve and process the diamonds contained within them. Another company official summed up what was clearly a deteriorating situation at the time in an interview, highlighting how 'The town almost depends on GCD to survive and if GCD is not there, Akwatia town is not there'.

Figure 2: Annual diamond production in Ghana 1920 to 2014

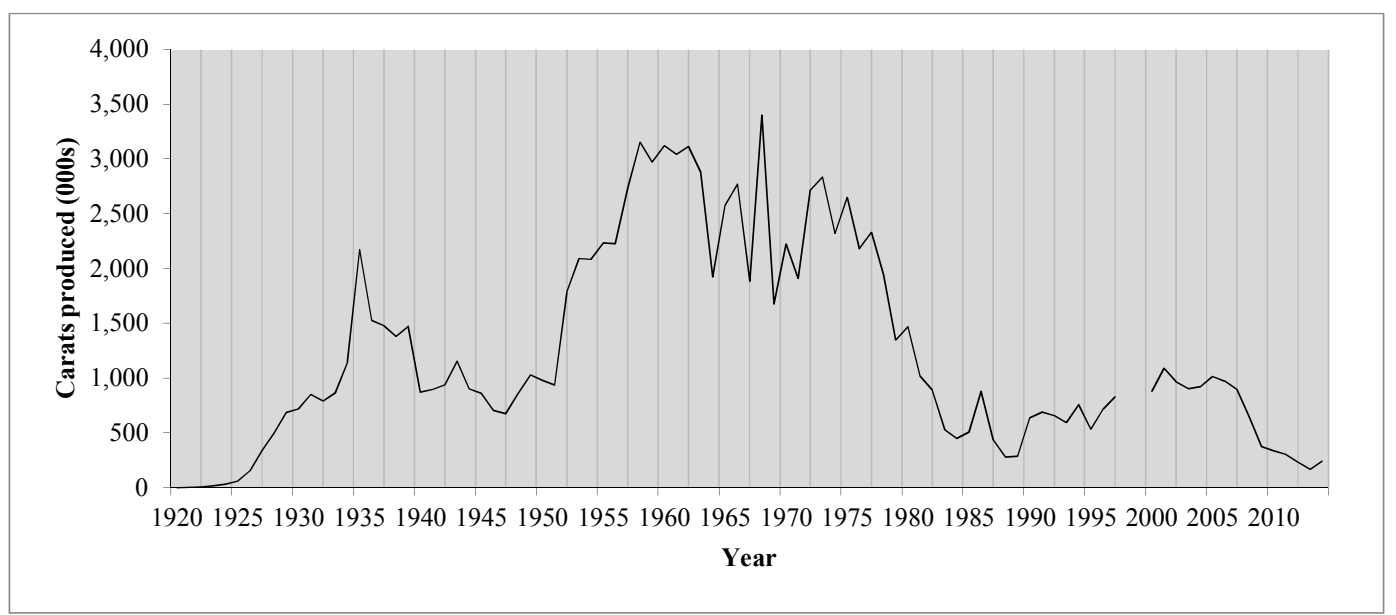

Sources: Data extracted from Chirico et al., 2010 and KPC, 2016. Note: no data exist for 1998 and 1999.

${ }^{9}$ Interview, GCD Surveyor, 19 November 2015, Ákwatia. 
These layoffs, coupled with a decline in diamond production (see Figure 2) and unpaid salaries, mobilized most of the remaining and former employees who, following clashes with security and police, started to engage in dialogue with GCD management. A deal was eventually struck which spawned the Tributer System, described variously as a 'marriage of convenience' (Nyame and Danso, 2006) and 'peaceful cohabitation'10 between GCD and artisanal miners. A company official elaborated on the agreement in an interview:

In a way it's a symbiotic relationship. They [tributers] feed off our [the company's] leftovers but they also sometimes have their native - you know - technology...they are geologists in their own right they find something then we go there and do some work and establish what they may have found. But they have also been helping us in policing the property, Ok, they be helping us because they, when you don't belong to the group and you doing any work they [alert] us and then we come. ${ }^{11}$

Reflecting once again on how, in the literature, 'the firm' has been projected as the focal point of GPNs, it is clear that in Akwatia, the changes that have occurred since GCD management implemented the Tributer System have galvanized and fortified the artisanal diamond mining networks and structures found in the town today. Two developments in particular stand out.

First, and following a blueprint reminiscent of that prescribed by De Soto $(2000,2002)$ based on experiences in urban Peru, as part of the arrangement, GCD management 'formalized' the scores of former and existing employees who were mining illegally on the company's concession, therefore officializing their existence as 'tributers'. Each was given an ID card; required to sell all stones to the company; and made to pay a nominal fee for each employee. These rules still apply: applicants must first identify a plot of land on the company concession that has been put aside for small-scale miners and/or has been worked by GCD (specifically, areas where the ore grade is low or it has been deemed uneconomical by management for the company to mine), must undergo health checks at the company hospital, and cannot work until the Survey Department gives its approval. Upon meeting these criteria, the application is forwarded to the GCD Tributer Committee, which represents all

\footnotetext{
${ }^{10}$ Interview, 20 August 2014, GCDL Board Member, Accra.

${ }^{11}$ Interview, GCDL Board Member, 20 August 2014, Accra.
} 
small-scale miners on the concession and acts as the formal grievance and communication mechanism between the two parties. Once approved, the tributer must pay compensation to the landowner and farmer (if present), at an amount decided by GCD. As part of the formal process, the tributer is given a basic induction concerning security, health and safety and a list of 'do's' and 'don'ts', which are listed in Appendix 1 of the Tributer Mining System pack (GCDL, 2011; Hilson and Clifford, 2010).

The second development was the establishment of the Belgium Market, which, and reinforcing points raised by Phillips (2011), is very much at the interface of Ghana's formal and informal alluvial diamond mining economies. Located at the Akwatia 'Junction', a small cul-de-sac, the Belgium Market is comprised of 10-15 dilapidated stalls and shacks, each manned by a buyer and/or sponsor. Today, it is main selling and buying point for diamonds in Ghana, chiefly because of GCD's ongoing struggles to offer competitive prices for stones harvested by tributers (Hilson, 2010; Hilson and Clifford, 2010). A company official confirmed as much in an interview, explaining that ' 40 to 60 per cent [of stones were] at least was[ting] away'. ${ }^{12}$ Several miners reported the same:

'[GCD] will pay you but the money is not enough as from the [Belgium] market'. ${ }^{13}$

'[I sell] part GCD and part my sponsor... I send it to my sponsor it is very higher than there $[\mathrm{GCD}]$... we are supposed to sell everything to them [GCD], but because of all the [sponsors], yeah ... it's verbal, yeah verbal agreement.' 14

'[GCD]...they will delay payment...maybe three days, four day...That is their own way of doing things. Maybe it have to go through processes. ${ }^{15}$

The reference made in the second quotation to a 'sponsor' requires further explanation. Several interviewees hinted that the Belgium Market is now the location of a complex network founded on trust-based relationships, and built around informal financing or sponsorship. Many tributers now sell a sizable percentage of their stones here to sponsors, debtors, chiefs, and land owners, all of whom reside in, or have links to, the market - a

\footnotetext{
${ }^{12}$ Interview, GCDL Board Member, Accra, 20 August 2014.

${ }^{13}$ Interview, Diamond Dealer, 4 August 2014, Belgian Market, Akwatia.

${ }^{14}$ Interview, Tributer, 5 August 2014, Mine Site, Akwatia.

${ }^{15}$ Interview, A Chief, 4 August 2014, Chief compound Akwatia.
} 
testament to the true 'horizontalness' which now prevails at the grassroots levels of Ghana's alluvial diamond chain. In GPN language, these complex sponsorship arrangements have had the effect of 'embedding' the tributer in the nodes of the supply chain which the Belgium Market traverses. This became clear during an interview with one local diamond dealer:

Every time I send diamonds to him [my sponsor at PMMC] ... at times he says 'Nana, are you short of money?' If I say 'yes' then he will give me something...You see, maybe I will credit some from the customers, you see, then the money will be more than what he will buy from me...Ok, the ten thousand dollars maybe I will be buy the diamond for .... two weeks...Two weeks when I buy the diamonds [and the money has] finish. I send back to him. He buy from me. Then the ten thousand dollars when he finish buying he will deduct the money from it. Deduct his money and give my money back. If I say 'eh, me ok, I need another ten thousand'... ${ }^{16}$

The GCD officials consulted seemed to recognize the semi-informality created by the company's struggles to purchase diamonds from tributers but were accepting of the growing importance of the Belgium Market in light of this failure. One in particular was very sympathetic, explaining that 'The law says they [tributers] should sell everything to us...[but] you see of late mining has become increasingly costly, so the tributers most of the time they don't have the money, that kind of money, so they go for sponsors, so some of the partners team up with people who have money and those people also demand the product [diamonds]...it is not the law but we give them quota to bring'. ${ }^{17}$

In another De Soto-like move, the Government of Ghana, concerned about smuggling, moved swiftly to legalize the semi-informal trading activities in the Belgium Market (Hilson and Clifford, 2010; PMMC, 2016). It accomplished this by first 'legitimizing' the activities of the diamond dealers trading in Akwatia, as indicated, calling on PMMC to award licenses to this group in exchange for a nominal fee ( 5 cedis), a move which has stimulated additional economic activity in the market. It simultaneously issued a second tier of license, renewable annually for a fee of 200 cedis, which permits a holder to sell diamonds purchased from local dealers to any of the licensed exporters based at 'Diamond House' in Accra. This formalized buying structure has not only helped to build trust and fortify relations among the many

${ }^{16}$ Interview, local diamond dealer, 26 November 2015, Akwatia.

${ }^{17}$ Interview, GCDL Manager, 24 November, 2015, Akwatia. 
actors now found in the Belgium Market (Table 2) but has also provided a platform that has stimulated a host of additional - largely undocumented - 'horizontal' transactions at the base of the alluvial diamond supply chain in Ghana responsible for the vertical 'progression' of stones.

The following excerpts from two interviews capture this succinctly, providing a flavour of the types of transactions which take place in the market:

Sometimes too the 'road pickers' too when they find a big diamond, they sometimes think that those who are close to them cannot buy [bush buyers] so they have to just bring it down to the house [i.e. the town/Belgium Market] to sell it. Because they think they can get better price in the house than in the bush since it's a big diamond and with high quality... They sometimes ask... 'oh, today I couldn't go to the road so just give me one cedi, give me two cedis...Yeah, you have to give them, otherwise if he find diamond he will never sell it to you. He will tell you 'oh, this guy is very wicked guy, so he won't'... 18

That, some people will go for the bush. And work for the land. [It] pass[es] about 6 or 7 people hands. It can come to you straight, it will pass two, three to four hands [before it comes to the Belgium Market]. ${ }^{19}$

In summary, and in line with the conceptual work produced on the GPN, Ghana's alluvial diamond supply chain does, indeed, revolve around a 'firm'. But it does so differently to how conventional GPN analysis projects the role of the firm: as a dominant centrepiece that makes business-related decisions that spawn and galvanize local networks, and which trigger a clustering of local industries. In the case of Akwatia, however, whilst the contemporary alluvial diamond mining economy has emerged on the back of the large-scale firm, GCD, its very existence is owed to the struggles of managers to keep the company solvent and deliver on promises made at the time the Tributer System was launched. The Tributer System was supposedly 'introduced by the company as a social intervention' and touted as 'a way of

\footnotetext{
${ }^{18}$ Interview, local diamond dealer, 26 November 2015, Akwatia. 'Road pickers' are individuals who walk around, with their heads positioned downward, 'looking' for rough stones along the dirt tracks of the Akwatia concession that have fallen off of trucks loaded with diamondiferous ore or which have been washed out following heavy rains.

${ }^{19}$ Interview, local diamond dealer, 26 November 2015, Akwatia.
} 
generating employment for the community and Ghanaians in general to improve upon their standard of living' (GCDL, 2011). Yet, it has been solely this 'marriage of convenience' that has kept it afloat: whereas in 1989, tributers were producing forty per cent of GCD's diamonds, by 2001 this figure had risen to 95 per cent, and by 2007 almost 100 per cent (865,610 carats valued at over US\$27 million) were mined by artisanal miners operating on the concession (Hilson, 2010: 303; Hilson and Clifford, 2010). It is against the background of this network embeddedness that power and value are now explored.

Table 2: Actors in the Ghana diamond production network

\begin{tabular}{|c|c|}
\hline Stakeholder & Description \\
\hline $\begin{array}{l}\text { Licensed Buying } \\
\text { Company }\end{array}$ & $\begin{array}{l}\text { A company licensed by PMMC to purchase and export rough diamonds from Ghana. Presently, there are } 11 \text { companies located in } \\
\text { designated offices in Diamond House, Accra (PMMC); the majority are foreign owned and operated. License application forms cost } \\
\text { US } \$ 1,200 \text { to process, and the license is US } \$ 18,000 \text {; renewed annually for US } \$ 12,000 \text {. Diamonds are purchased from local buyers (also } \\
\text { licensed by PMMC) through bank-to-bank payments, and are stored in the PMMC vault daily. On request of the company, PMMC } \\
\text { processes export at a fee of } 2.3 \text { per cent per parcel. Companies must buy from all local diamond buyers, though, reportedly, companies } \\
\text { may act as sponsors pre-financing local buyers to ensure a supply of the diamonds needed. The finance is deducted from the final } \\
\text { payment to the local buyer. }\end{array}$ \\
\hline Sponsor & $\begin{array}{l}\text { An informal lender providing finance to actors at all levels in the supply chain. In Akwatia, sponsors finance tributer license holders, } \\
\text { entering various agreements usually involving payment in diamonds bought from the tributer at a below market rate. Sponsoring at the } \\
\text { local level also occurs between sponsors, buyers, and dealers as well as the provision of 'chop' money to individuals such as 'road } \\
\text { pickers' and labourers so that they will sell their diamonds back to them in the future. }\end{array}$ \\
\hline Tributer & $\begin{array}{l}\text { Licensed directly by GCD to mine a demarcated plot of land on the concession. Tributers must meet various conditions and join the } \\
\text { Tributer Miners Association before being issued with an ID card. The license is purchased directly from GCD. Tributers usually enter } \\
\text { partnerships with sponsors to finance their operations, and in return sell a proportion of diamonds mined at pre-agreed rate per carat. }\end{array}$ \\
\hline $\begin{array}{l}\text { Licensed Diamond } \\
\text { Buyer }\end{array}$ & $\begin{array}{l}\text { A buyer licensed by PMMC to purchase diamonds in Ghana only. All buyers must be Ghanaian citizens. There are two levels of buyer } \\
\text { license: 1) allows buyers to trade in diamonds at the local level and establish a local buying office in Belgian Market, and; 2) allows } \\
\text { buyers to sell diamonds to licensed buying companies in Diamond House, Accra. These buyers may be sponsored and also sponsor } \\
\text { other actors. }\end{array}$ \\
\hline $\begin{array}{l}\text { Informal Diamond } \\
\text { Buyer / Dealer }\end{array}$ & $\begin{array}{l}\text { Diamond buyers and dealers operating informally in Akwatia, surrounding communities, and at mine sites. The trading activities of this } \\
\text { group of unlicensed buyers and dealers are where the majority of horizontal sales and changing of hands occurs. Each has their own } \\
\text { strategy depending on their agency and finances at their disposal. Some act as 'bush buyers' travelling to mine sites daily before return } \\
\text { to Belgian Market each morning to trade, others stay in Akwatia town but do not have a formal office in Belgian Market, and many are } \\
\text { also know to sponsor small amounts of 'chop' money to secure they can purchase diamonds at favourable rates. Virtually anyone in } \\
\text { Akwatia buying and selling diamonds without a PMMC license may be considered to fall into this category. }\end{array}$ \\
\hline Labourer & $\begin{array}{l}\text { Employed by tributers to work at their concessions. Undertake the physical work at mine sites in three-week cycles (Figure } 3 \text { ). Often } \\
\text { receive 'chop' money to enable them to work over the three weeks while the gravels are being processed. They have limited, if any, } \\
\text { health and safety equipment, may rent equipment daily, and are highly mobile; able to move between mine sites at the end of each } \\
\text { cycle. }\end{array}$ \\
\hline Unlicensed Miner & Unlicensed miners organized independently or in small 'gangs' (one to three) that mine in the rivers and near tributer concessions. \\
\hline Road Picker & $\begin{array}{l}\text { Individuals who walk around looking down at the dirt tracks that dissect the GCD concession in the hope to find rough stones that have } \\
\text { fallen off trucks loaded with diamondiferous ore or that have been washed out after heavy rains. }\end{array}$ \\
\hline Equipment Renter & $\begin{array}{l}\text { Rent head pans, sieves (jigs), spades and other equipment to labourers at some mine sites in return for a portion (usually } 1 \text { bucket) of } \\
\text { diamondiferous concentrate. All equipment renters are women who work in groups of five to eight and rent to the same labourers each } \\
\text { day. }\end{array}$ \\
\hline
\end{tabular}

Sources: PMMC (2016); GCDL (2011; 2016); Various Interviews (2014 to 2015). Note: There are not always distinct boundaries between some of these ASM stakeholders. Many people in Akwatia shift between or undertake a number of these roles and livelihood strategies at the same time.

\section{Power and value}

Both power and value are examined together here because in Akwatia, they cannot be separated. This resonates powerfully with Henderson et al. (2002: 450), who argued that 'the source of power within GPNs and the ways in which it is exercised is decisive for value enhancement and capture and thus for the prospects of development and prosperity'. As with 
embeddedness, however, the power dynamics that have surfaced and value created in Ghana's alluvial diamond mining economy have done so in the semi-informal 'space', once again courtesy of the large firm failing to deliver on promises its management made at the time the Tributer System was implemented. But more broadly, and as will be explained, it has been the governance structure in place for alluvial diamond mining - in addition to the GCDL-managed Tributer System, the influence of, and inputs from, PMMC, the Ministry of Lands and Natural Resources, and the chieftaincy institution - that has truly shaped the power dynamics and value in the sector.

The three-pronged notion of power (corporate, institutional, and collective) put forward by Henderson et al. (2002) ignores empowerment in the way in which it has been critiqued in the international development literature (e.g. Alsop et al., 2006; Freire, 1970; Ibrahim and Alkire, 2007; Narayan, 2002; Rowlands, 1997; Sen, 1989, 1999; Willis, 2011). It is also incapable of articulating very effectively the power and labour dynamics of a GPN, in this case, the complex horizontal relationships found throughout the base of the alluvial diamond supply chain. For the purposes of this discussion, therefore, power is re-conceptualized, taking into account 'empowerment' as the 'interplay between two fundamental components' (McQuilken, 2016: 184), namely: 1) agency, or the ability of an actor (or group) to make purposeful choices concerning what they value; and 2) the extent to which the surrounding opportunity structure (formal and informal regulations, actors, institutions, etc.) enables or inhibits this agency (Alsop et al., 2006; Ibrahim and Alkire, 2007; Narayan, 2002; Sen, 1989, 1999). When applied to Akwatia, it is the rather unique governance system now in place for alluvial diamond mining, characterized by a company unable to fulfill its obligations as part of an agreement forged with the town's residents, a semi-formal licensing scheme installed by PMMC, a local chief who periodically extracts surface rent, and a Ministry of Lands and Natural Resources which leaves GCDL to its own devices and seems to have little interest in further supporting the sector, that has been 'the opportunity structure' for operators to exercise their agency.

As of November 2015, there were 240 tributers registered with the firm, GCDL. But due to a shortage of investment, only 10-20 were actively working their concessions at the time. As explained, through issuing individual licenses under the Tributer System, GCDL has, at least on paper, some power over the ASM activities on its concession, and ensures some level of accountability through its scheme of mandatory payments. But despite this framework, and 
the costs of tributer licenses being relatively affordable and quick to obtain, ${ }^{20}$ a dearth of state-led support services and the absence of a conducive policy framework that facilitates access to development finance, it is ultimately the series of informal sponsors and financiers who determine the agency of operators and hold the power in the lower rungs of the supply chain. One tributer explained in an interview that it is not uncommon to have several sponsors in a chain:

If you were born in the locality [Akwatia] ... by all means you will have a friend, but if you are stranger it will be difficult for you unless you have a friend who can link you to this business ... we have the local sponsorship, we have the, I can say national, if you go to Accra you will have national sponsorship, and then we have international ... I can say the [maximum] is about five [people in the chain of sponsorship] ... I have a friend in Accra, he also has a white man friend, he's international business, he says he's going to contact his boss from Dubai. And Dubai too has a person at India or any other country, yeah so from India or from UK, from anywhere. ${ }^{21}$

These informal agreements and local-level dynamics determine value, in turn, dictating whose hands diamonds pass through in the various nodes of the production network. In the original GPN framework, a firm is seen to create, enhance and capture it (Henderson et al., 2002). The GCD Tributer System is certainly an example of a firm creating value through an economic rent. But other forms of value also apply to Akwatia, which, very importantly, have contributed to the 'horizontalness' of nodes. Notably, tributers reportedly create value through informally sub-letting or 'parceling out' their plots to smaller groups of miners; organizing the labour structures and payment arrangements at their site in certain ways; and investing in particular technologies, such as crushing and washing machines. They capture value through informal sponsorship and buying agreements, as another tributer explained in an interview:

At time[s] maybe some [tributers] ... create a portion to every worker and if you get the portion then the gravels outside will be divided into three, then the worker will take one

\footnotetext{
${ }^{20}$ This differs sharply from the experiences of those who apply for a small-scale gold mining license to work elsewhere in Ghana (Hilson and Potter; Hilson et al., 2014; McQuilken and Hilson, 2016). As one tributer explained, 'as for the license for the minerals commission its different as for the tributer [system].... a week or two weeks for everything that's all' (Interview, Tributer, 25 November 2015).

${ }^{21}$ Interview, Tributer, 20 November 2015, Akwatia.
} 
part and then take away, and then you the owner take the two. But here, no, everything, wash everything, I buy [all the diamonds] and pay you ... I have acquired this experience [strategy] for a long time, I've been working for about twenty-two years, so I been studying when you do this and you get this and you do. I balance things and see where I make money and where I make these things. That's why. ${ }^{22}$

From the interview feedback, it appears that such informal 'value enhancing' arrangements are commonplace across Akwatia.

Further reinforcing assertions made by Phillips (2011), the synergies that have developed between the informal and formal sectors seem to have positively affected value in the former. Consider, for example, the case of one local buyer based in the Belgium Market. The buyer stated, in an interview, that he borrows anywhere from US\$10,000 to US $\$ 30,000$, five-six times annually, from his Indian sponsor at Diamond House in Accra. This, he explained, was made possible by the trust built with the Indian sponsor over many years. He indicated that this steady inflow of funds enables him to sponsor 20-30 additional local buyers in Akwatia, which puts him in a position to bring a combined 400-500 carats of diamonds to his sponsor monthly:

At times me too, I consider some people and give them some money to buy, so they go to the villages and buy and bring it to me. So some I give them 500 dollars...It ranges from $\$ 200$ to $\$ 2000$ [US dollars] ... by five days they will bring me the diamond and I will deduct my money...I buy from them...now... 110 to 115 [cedis per carat, and sell for] 120 . At times too, I buy from them for 120 to 125 [cedis per carat]. At times too I buy more than that, depending on the quality. ${ }^{23}$

If these informal financial arrangements were not in place at all levels of Ghana's diamond supply chain, the entire Tributer System and most of the mining activities found in and around Akwatia today would likely collapse. An in-depth interview with a tributer and his sponsor (they claimed to have known one another for over 20 years) at a newly-demarcated plot shed light on the start-up costs for tributers (hefty investment costs of as high as

${ }^{22}$ Interview, Tributer, 5 August, 2014, Mine Site, Akwatia.

${ }^{23}$ Interview, local diamond dealer, 26 November 2015, Akwatia. 
US\$60,000 over a three-month period). ${ }^{24}$ The hefty sums involved suggest that there are hidden networks of sponsorship in the lower rungs of the supply chain, and that longestablished trust-based relationships are responsible for mobilizing significant quantities of money upfront:

Oh, we invest.... Its 'costive', very, very 'costive', because you will pay, errm, rent excavator eight hours you will pay 1700 for eight hours ... then buy the diesel 840 Ghana cedis for eight hours. Then operator, operator the machine eight hours he will get the chop one as 150 Ghana cedis. ${ }^{25}$

These, however, are not the only costs involved; nor is it the only way that those working in the sector and surrounding service industries make their livings and create, enhance, and capture value (See, once again, Table 2). Though every ASM site has its own sponsor and has a unique organization structure, one of the more popular arrangements among those interviewed, and indeed common across all operations, is what is referred to locally as 'sharing'. For those who are a part of such an arrangement, once diamondiferous ore has been exposed or removed, it is divided, usually into three, with a portion going to the tributer, one to the sponsor and one to the labourers. A closer examination of the dynamics of a 'sharing' arrangement captures the essence of the 'horizontalness' of the nodes which Akwatia traverses, as well as provides insight into the multiple forms power and value can take here.

${ }^{24}$ To ensure the sponsor maintains cash-flow, the owner of the excavator is paid upfront every 10 days using monies obtained from diamond sales.

${ }^{25}$ Interview, Tributer, 25 November 2015, Akwatia. 
Figure 3: Akwatia node of the GPN for diamonds and its 'artisanal production strand'

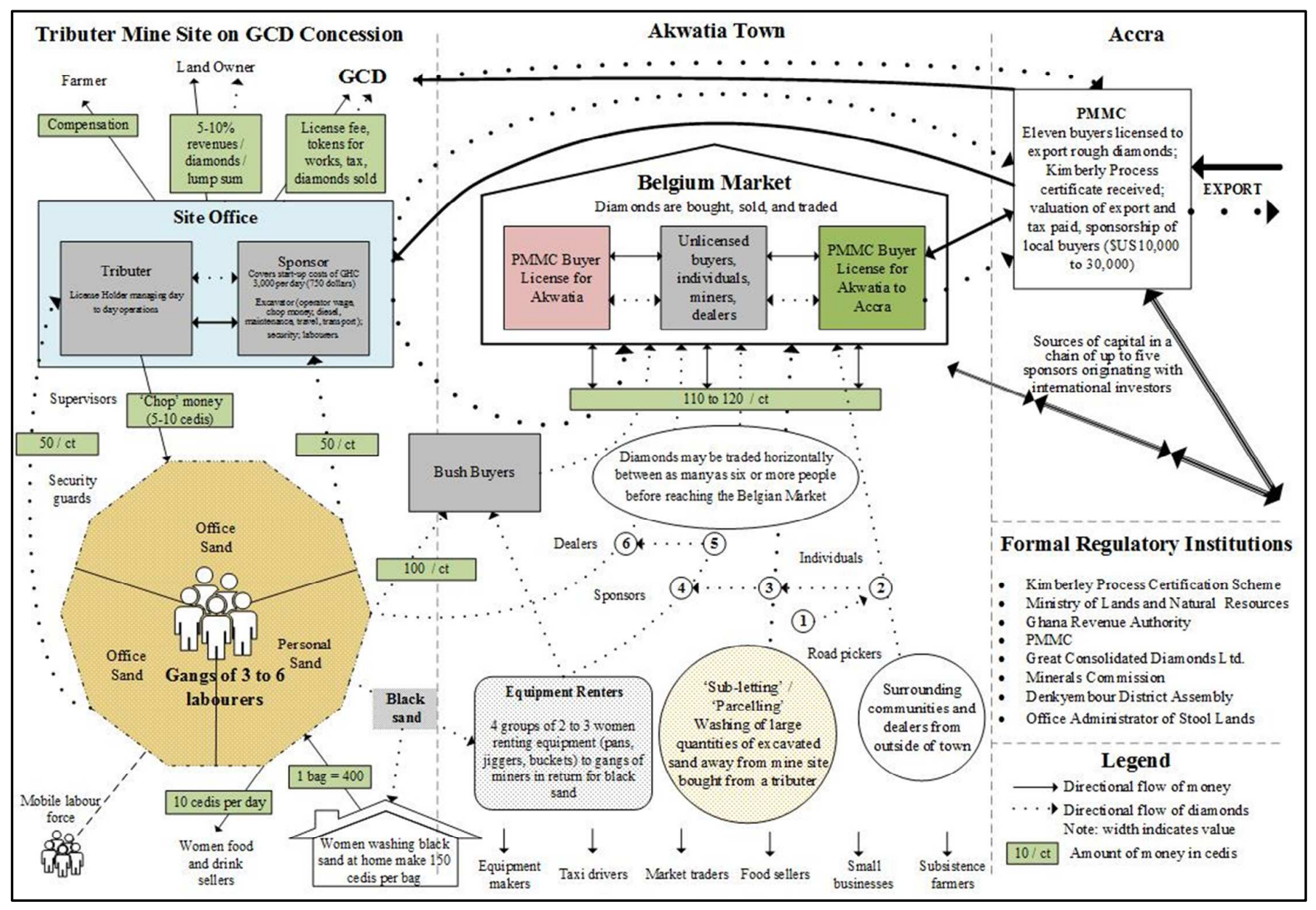

The 'sharing' site visited (see Figure 3 for a generalized depiction of the organizational structures in Akwatia) is a 2.5-acre plot that was purchased for 5000 cedis and employs 47 labourers, three security guards (two for the night and one for the day) and six supervisors. As is the case with all tributer plots in Akwatia, here, labourers are organized in 'gangs' of three-six people (usually men), who, over a three-week cycle, wash the gravel uncovered by an excavator using repurposed barrel drums with holes drilled into a removable lid that separates the larger stones from the sand. The resulting diamondiferous 'black sand' is then carried in head pans and organised into piles, each divided into three for the abovementioned parties. The gang will then work in knee-deep pools of water and support one-two 'jiggymen', who use a $60 \times 30 \mathrm{~cm}$ wooden box ('jig') with a fine metal mesh in the bottom to sift through the sand and find the diamonds. The entire process is overseen by the supervisors, who ensure that all of the diamonds are captured. Having 'jigged' the two piles of 'office sand' by the end of third week, each gang is accompanied by its supervisor to the 
office where all of the stones are weighed and bought by the tributer for approximately 50 cedis per carat. In an agreement brokered between the sponsor and the tributer, the latter then sells all diamonds to the former at a predetermined rate (approximately 100 cedis per carat). The sponsor then, reportedly, sells five per cent of the diamonds to GCDL, and the reminder in the Belgium Market or to a foreign buyer at PMMC, aiming to make a profit of 10-20 cedis per carat at a rate of 120 per carat. A 'good week' will yield 250 carats of diamonds.

Tributers are, in effect, de facto operations managers who oversee the entire mining operation throughout its lifecycle, and also pay the labourers the "chop money, ${ }^{26}$ of around five to 10 cedis daily needed to keep them going before the end of the three-week cycle when they receive payment. Having earned 50 cedis per carat for the office sand, the gangs are then free to sell whatever diamonds are won from their own 'third' of jigged sand. As they are one-two hours' walk from Belgium Market, many choose to sell to 'bush buyers', who travel to the mine site each day, usually buying at 100 cedis per carat before returning to the Belgium Market the following morning to sell their diamonds, also aiming to earn 10-20 per cent profit, although as one explained in an interview, at times, they struggle to break even:

In the morning when I wake, I go to Belgium. When the day breaks and I'm through with my rounds, then I come over to this place [mine site]. What I get here is what I go round with the following day... what I'm trying to say is you can buy diamonds here at 1 million [100 Ghana cedis] and then when go out there to sell you don't get your money back the actual money when you are not lucky. ${ }^{27}$

As this analysis illustrates quite clearly, in Akwatia's semi-formal 'space', these horizontal and often overlooked transactions which are fundamental to value-creation and shape the power dynamics at the lowest rungs of Ghana's alluvial diamond mining sector are catalyzed by the actions of the tributer.

As a point of departure, it is instructive to return to the firm-centric analysis which also dominates discussions on power and value in GPNs. Again, the artisanal diamond mining sector that flourishes in Akwatia today, the shapes of its networks and power structures, and the way in which value is created and enhanced within its nodes, has developed in a 'space'

${ }^{26}$ 'Chop' is pidgin English for 'eat' or 'to eat'.

${ }^{27}$ Interview, bush buyer, 23 November 2011, Akwatia. 
created by the firm which has been tasked with taking the lead on diamond production in Ghana (CAST, then GCD and now, GCDL). The control of Akwatia's alluvial diamond network by smaller players, however, is largely the 'product' of a 'large-scale bias' which permeates mining policy across sub-Saharan Africa: from A Strategy for African Mining (World Bank, 1992) through to the current Africa Mining Vision, the main objective, developmentally, has been to foster the growth of foreign-financed large-scale mineral exploration and extraction (Hilson, 2017). With ASM being a growing, yet comparatively peripheral, component of Africa's extractive industries and development agenda, there is reason to believe that Akwatia's alluvial diamond networks have managed to develop in the way they have because there is very little 'large-scale' interest beyond a GCDL firm with unclear motives. If the interest of international firms in Akwatia was to grow, these rungs of the supply chain would look very different, more reminiscent of the 'large-scale production' strand mentioned at the outset of this section of the paper.

\section{CONCLUDING REMARKS}

This article began by drawing attention to the glaring data needs of ASM, information which, if obtained, would help to fortify policy interventions aimed at formalizing and supporting the sector moving forward. As more governments commit to this exercise, identifying appropriate techniques to capture this information will become more of a priority. The article has attempted to apply the GPN framework, which, to date, has been used rather conservatively to map industries for which an abundance of information already exists, to conceptualize the complexities of ASM, to gather vital information about the sector, and to develop a more nuanced understanding of the interconnectedness of its key constituents. Obtaining this information can be even more challenging in informal ASM settings or semiinformal setups such as the alluvial diamond economy now rooted in Akwatia. It is, however, a first step toward bringing operators into the legal domain, where they can be regulated, monitored and supported more effectively. This inaugural analysis of the 'artisanal production strand' of the GPN for diamonds offers three very important insights.

The first concerns ASM itself, in particular, the heterogeneity of its workforce and activities, a phenomenon which Hilson and Potter (2005), Fisher (2007), Verbrugge (2015) and others have drawn attention to over the years in Development and Change. In order to make sense of the intricacies of the sector, and how it is mostly found rooted in the informal economy, a 
radical reconceptualization of its organization is needed. The GPN offers a much-needed lens to do this, providing valuable guidance theoretically and diagrammatically on how to map the many and varied complexities of ASM. Understanding the various processes, linkages and different roles that actors play is an essential starting point when formalizing ASM.

The second concerns the lack of analysis in the GPN literature on the informal economy. Aside from Phillips (2011), few have applied the framework to informal industries, which is inexplicable, given that this is the area where it could have its greatest impact. Whilst this article only offers a glimpse of the complexities of semi-formal diamond mining in Ghana, it has undoubtedly, with the guidance of the GPN literature, uncovered and shared valuable information which casts light on how the sector functions. In doing so, the analysis has revisited the earliest conceptualizations of the GPN, which were developed with the assumption that production and networks revolve and develop around a 'firm'. This is certainly the case in Akwatia but it is more so the inaction of a central firm which has shaped the embeddedness, power and value now found in the alluvial diamond mining structures firmly rooted in the town. The analysis shows quite clearly that as a framework for analyzing the nuances of the informal economy, the GPN is rather limited, conceptually. It can, however, be reworked and refined for this purpose, which should be a point of emphasis for the 'Manchester school' moving forward.

Finally, and an appropriate point for departure, it is essential to revisit the issue of 'horizontalness', a distinguishing attribute of the GPN. As illustrated by the case of alluvial diamond mining in Akwatia, the nodes found in informal industries can be complex, featuring an array of actors and numerous horizontal relationships and transactions. But perhaps geography scholarship needs to conceptualize this 'progression' differently, as 'horizontal' tends to connote a plateauing when, in fact, these relationships are essential in determining how value is created, enhanced and captured at each node. In informal economies, the boundaries of nodes are slightly more blurred, with different actors active at multiple 'levels' and linking different players. It is beyond the scope of this discussion to articulate this further but perhaps a more refined conceptualization, at least in informal sectors such as ASM, would be to view transactions 'diagonally', which would signify progression whilst at the same time, projecting this to be incremental. Regardless of the 
output, given the unpredictability of flows and movement of resources in informal spaces, a more refined conceptualization of 'movements' is needed.

With formalization of ASM moving fast up the international development agenda, donors and host governments will be pressed into action to retrieve the crucial information needed to inform the design of policies, laws and interventions. A radical change in approach will be needed to achieve this, which a modified GPN could inform. 


\section{References}

Alsop, R., M. Bertelsen and J. Holland (2006) 'Measuring Empowerment in Practice from Analysis to Implementation' Washington, D.C: World Bank.

Bain and Company (2011) The Global Diamond Industry, Lifting the Veil. Bain and Company and Antwerp World Diamond Centre private foundation (AWDC).

Bain and Company (2014) The Global Diamond Mining Industry, Portrait of Growth. Bain and Company and Antwerp World Diamond Centre private foundation (AWDC).

Banchirigah, S. (2008) 'Challenges with eradicating illegal mining in Ghana: A perspective from the grassroots', Resources Policy 33(1): 29-38.

Barrientos, S. (2013) 'Labour Chains': Analysing the Role of Labour Contractors in Global Production Networks' The Journal of Development Studies 49(8): 1058-1071.

Barrientos, S., G. Gereffi, G. and A. Rossi (2011) 'Economic and Social Upgrading in Global Production Networks: A New Paradigm for a Changing World'. International Labour Review 150(3-4): 319-340.

Barry, M. (1996) 'Regularizing Informal Mining: A Summary of the Proceedings of the International Roundtable on Artisanal Mining17-19 May 1995', Industry and Energy Department Occasional Paper No 6, Washington, DC: World Bank.

Bernstein, H. and L. Campling (2006a) 'Commodity Studies and Commodity Fetishism I: Trading Down', Journal of Agrarian Change 6(2): 239-264.

Bernstein, H. and L. Campling (2006b) 'Commodity Studies and Commodity Fetishism II: 'Profits with Principles?', Journal of Agrarian Change 6(3): 414-447.

Bridge, G. (2008) 'Global production networks and the extractive sector: governing resource based development', Journal of Economic Geography 8(3): 389-419.

Brooks, A. (2013) 'Stretching Global Production Networks: The International SecondHans Clothing Trade' Geoforum (44): 10-22.

Carswell, G. and G. De Neve (2013). 'Labouring for Global Markets: Conceptualising Labour Agency in Global Production Networks', Geoforum 44(1): 62-70.

Chirico, P., K. Malpeli, S. Anum, E. and E. Phillips (2011) Alluvial Diamond Resource Potential and Production Assessment of Ghana. Scientific Investigations Report 2010-5045: U.S. Geological Survey.

Cleaveland, T. (2014) Stones of Contention: A History of Africa's Diamonds in Robinson, D. and Millers, J. (eds.) Africa in World History Series. Ohio University Press. 
Coe, N. (2011) 'Geographies of production II A global production network A-Z', Progress in Human Geography 36(3): 389-402.

Coe, N., and M. Hess (2013) 'Global Production Networks, Labour and Development', Geoforum 44(1): 4-9.

Coe, N., M. Hess, H. Yeung, P. Dicken and J. Henderson (2004). “'Globalizing' Regional Development: A Global Production Networks Perspective', Transaction of The Institute of British Geographers, 29(4): 468-484.

Coe, N., P. Dicken and M. Hess (2008). 'Global Production Networks: Realizing the potential', Journal of Economic Geography 8(3): 271-295.

Coe, N.M., P.F. Kelly and Yeung, H.W-C (2007) Economic Geography: A Contemporary Introduction. Oxford: Blackwell.

CRC Sogema (2014) Mission Report: Scoping Study of the Mining Supply Chain in Ethiopia. Paper prepared for the Department of Foreign Affairs, Trade and Development Canada, Ottawa.

D’Angelo, L. (2015). 'Diamond mining is a chain': Luck, gambling and blessing in Sierra Leone's artisanal diamond mines', Critical African Studies 7(3): 243-261.

Da Silva-Glasgow, D. (2013) 'Global Value Chain Analysis of the Gold Jewellery Industry: Upgrading Trajectories for Guyana'. Caribbean Centre for Competitiveness, Institute of Critical Thinking: University of West Indies.

Davidson, J. 1993. The transformation and successful development of small-scale mining enterprises in developing countries. Natural Resources Forum 17(4): 315-326.

Dejong, T. (2013). Diamond Mining in Cote D'Ivoire: Programming Options for the Artisanal Mining Sector. Diamond Development Initiative, Ottawa.

De Soto, H (2000) The Mystery of Capital: Why Capitalism Triumphs in the West and Fails Everywhere Else. New York: Basic Books.

De Soto, H. 2002. The Other Path: The Economic Answer to Terrorism. New York: Basic Books.

Dicken, P. (2011). Global Shift: Mapping the Changing Contours of the World Economy. London: SAGE.

Dos Santos, R.S.P., B. Milanez. (2015) 'The Global Production Network for iron ore: materiality, strategies, and social contestation in Brazil, The Extractive Industries and Society, 2: 756-765.

Eftimie, A., Heller, K., Strongman, J., Hinton, J., Lahiri-Dutt, K., Mutemeri, N., Insouvanh, C., Sambo, M., and Wagner, S., (2012). Gender Dimensions of Artisanal and 
Small-Scale Mining. A Rapid Assessment Toolkit. The World Bank, Gender Action Plan.

Engelshoven, M. (1999) 'Diamond and Patels: A report on the diamond industry of Surat', Contributions to Indian Sociology, 33: 353-377.

Engwicht, N. (2016). After Blood Diamonds: The Moral Economy of Illegality in the Sierra Leonean Diamond Market. Max-Planck-Institut für Gesellschaftsforschung, Köln.

Fisher, E (2007) 'Occupying the margins: labour integration and social exclusion in artisanal mining in Tanzania', Development and Change 38(4): 735-760.

Fold, N., J.B. Jonsson and P. Yankson (2013) 'Buying into Formalization? State institutions and interlocked markets in African small-scale gold mining'. Futures 62(A):128139.

Freire, P. (1970) Pedagogy of the oppressed, 30th anniversary edition (2005). New York: Continuum International Publishing Group.

Freudenberger, M., Thiam, B., Picard, C., Jiekak, S., and T DeJong (2013). Property Rights Conundrums in Artisanal and Small-Scale Mining: Experiences from USAID Projects in Cote d'Ivoire, Guinea, and the Democratic Republic of Congo. Paper presented at the World Bank Conference on Land an Property, 23-27 March 2015, World Bank, Washington DC.

GCDGL (Great Consolidated Diamonds Ghana Limited) (2016). 'Great Consolidated Diamonds Ghana Limited, About Us' http://gcdgl.com/cat_select.php?linkID=1 (Accessed 15 June 2016).

GCDL (Great Consolidated Diamonds Ghana Limited) (2011) 'Tributer Mining System' Unpublished Company Document, Great Consolidated Diamonds Ghana Limited.

Gereffi, G. (1994) 'The Organization of Buyer-driven Global Commodity Chains: How US Retailers Shape Overseas Production Networks', in G. Gereffi and M. Korzeniewicz (eds.) Commodity Chains Global Capitalism, pp. 95-122. Praeger, Westport, CT

Gereffi, G. (1999) 'International Trade and Industrial Upgrading in the Apparel Commodity Chain', Journal of International Economics 48(1): 37-70.

Gereffi, G. (2005) The Global Economy: Organization, Governance, and Development, pp. 160-182, in The Handbook of Economic Sociology (ed. N.J. Smelser and R. Swedberg), New Jersey: Princeton University Press.

Gereffi, G., J. Humphrey and Sturgeon, T. (2005) 'The Global Governance of Value Chains' Review of International Political Economy 12(1): 78-104. 
Ghana Government (2016) 'Ministry of Lands and Natural Resources' http://ghana.gov.gh/index.php/blog-categories/blog-donec-eu-elit-in-nisi/94-ministriesinfo/378-ministry-of-lands-and-natural-resources (Accessed 20 June 2016).

Ghana Legal (2015) 'Ghana Legal Home Page'. http://cases.ghanalegal.com (Accessed 21 June 2016).

Ghana Statistical Service (2014). 2010 Population and Housing Census, District Analytical Report, Denkyembour District. Ghana Statistical Service.

Global Witness. (2006). The Truth About Diamonds. London: Global Witness.

Greenhalgh, P. (1985) West African Diamonds 1919-83 An Economic History. Manchester University Press.

Helleiner, E. (2006) 'Reinterpreting Bretton Woods: International Development and the Neglected Origins of Embedded Liberalism', Development and Change 37(5): 943-67.

Henderson, J., P. Dicken, M. Hess, N. Coe, and H. Yeung (2002) 'Global Production Networks and the Analysis of Economic Development. Review of International Political Economy 9(3): 436-464.

Hentschel, T., F. Hruschka, M. Priester (2002) Global Report on Artisanal and SmallScale Mining. Mining, Minerals and Sustainable Development Project Working Paper 70, London: International Institute for Environment and Development.

Hilson, C.J., (2006). Poverty and economic development in West Africa: a historical analysis. In Hilson, G.M. (eds.) Small-Scale Mining, Rural Subsistence and Poverty in West Africa, Intermediate Technology Publications Ltd, Rugby, UK, pp. 13-23.

Hilson, G. (2001) A Contextual Review of the Ghanaian Small-Scale Mining Industry. Minerals Mining and Sustainable Development, International Institute of Environment and Development.

Hilson, G. (2010) 'Once a miner, always a miner': Poverty and livelihood diversification in Akwatia, Ghana. Journal of Rural Studies 26(3) 296-307.

Hilson, G. (2012) 'Family work and cultural values: child labor in Malian artisanal gold mining communities', World Development, 40(8), 1663-74.

Hilson, G. (2013) 'Creating' rural informality: the case of artisanal gold mining in subSaharan Africa. The SAIS Review of International Affairs 33(1) 51-64. https://muse.jhu.edu/article/511217.

Hilson, G. (2017) 'Why is there a large-scale mining 'Bias' in sub-Saharan Africa?' Land Use Policy (in press), DOI http://dx.doi.org/10.1016/j.landusepol.2017.02.013 
Hilson, G. and J. McQuilken (2014) 'Four Decades Of Support For Artisanal And SmallScale Mining in Sub-Saharan Africa: A Critical Review.' The Extractive Industries and Society 1(1) 104-118.

Hilson, G. and Potter, C (2005) 'Structural adjustment and subsistence industry: artisanal gold mining in Ghana'. Development and Change, 36(1): 103-131.

Hilson, G., and Garforth, C.J. 2013. 'Everyone now is concentrating on the mining': Drivers and Implications of Changing Agrarian Patterns in the Eastern Region of Ghana. The Journal of Development Studies, 49(3), 348-362.

Hilson, G., and M. Clifford (2010) 'A 'Kimberley protest': Diamond mining, export sanctions, and poverty in Akwatia, Ghana' African Affairs 109 (436): 431-450.

Hilson, G., Hilson, A., Adu-Darko, E. 2014. Chinese Participation in Ghana's Informal Gold Mining Economy: Drivers, Implications and Clarifications. Journal of Rural Studies 34: 292-302.

Hirway, I. (2009) Losing the Sparkle; Impact of Global Crisis o the Diamond Cutting and Polishing Industry in India, UNDP India.

Hopkins, T., and I. Wallerstein (1986) 'Commodity chains in the world-economy prior to 1800', Review (Fernand Braudel Center): 157-170.

HRW (Human Rights Watch) (2015) Precious Metal and Cheap Labor, Child Labor and Corporate Social Responsibility in Ghana's Artisanal Gold Mines. Human Rights Watch, New York.

Hughes, A., Wrgley, N., and M. Buttle (2008) 'Global production networks, ethical campaigning, and the embeddedness of responsible governance', Journal of Economic Geography 8(3): 345-367.

Ibrahim, S., and S. Alkire (2007) 'Agency and Empowerment: A Proposal for Internationally Comparable Indicators', Oxford Development Studies 35(4): 379-403.

ICMM (International Council on Mining and Minerals) (2015) 'Mining in Ghana - What Future can we Expect? Mining: Partnerships for Development', International Council on Mining and Minerals.

ILO, International Labour Organization (1999). Social and labour issues in small-scale mines. Report for Discussion at the Tripartite Meeting on Social and Labour Issues in Smallscale Mines, International Labour Organization, Sectorial Activities Programme, International Labour Office, Geneva.

Janse, A (2007) 'Global Rough Diamond Production Since 1870', Gems and Gemology 43(2): 98-119. 
Kamlongera, P. (2011) 'Making the Poor 'Poorer' or Alleviating Poverty? Artisanal Mining Livelihoods in Rural Malawi' International Development (23)8: 1128-1139.

KP (Kimberley Process) (2016) 'Kimberley Process, About Us' https://www.kimberleyprocess.com/en/about (Accessed 25 June 2016).

KPC (Kimberley Process Certification) (2016) 'Kimberley Process Rough Diamonds Statistics, Public Statistics Area, Annual Summary Tables, 2009 to 2014' https://kimberleyprocessstatistics.org/public_statistics (Accessed June 20 2016).

Maconachie, R (2011) 'Re-agrarianizing livelihoods in post-conflict Sierra Leone? Mineral wealth and rural change in artisanal and small-scale mining communities', Journal of International Development 23(8): 1054-1067.

Levin, E., and J. Hinton (2010) Comparative Study: Legal and Fiscal Regimes for Artisanal Diamond Mining. USAID, Washington DC.

Maconachie, R and T. Binns (2007) 'Farming miners' or 'mining farmers'? Diamond mining and rural development in post-conflict Sierra Leone', Journal of Rural Studies 23(3): $367-380$.

Mahama C A and O. Baffour (2009) 'Management of Stool Land Revenue in Ghana: A study of the Nkawie and Toase Stools of the Atwima Nwabiagya District of the Ashanti Region 'Journal of Science and Technology 29(1): 28-38.

McQuilken, J. (2016) ' Ethical Gold' in sub-Saharan Africa: A Viable Empowerment Strategy?' International Development Planning Review 38(2): 179-199.

McQuilken, J. and G. Hilson (2016) Towards Inclusive Formalisation of ASM in Ghana: Background Research for an Action Dialogue. International Institute of Environment and Development.

MinCom (Minerals Commission) (2016) 'Welcome to Minerals Commission' www.eservices.gov.gh/MINCOM/SitePages/MINCOM-Home.aspx (Accessed 20 June 2016).

MLNR (Ministry of Lands and Natural Resources (2016) 'Office of the Administrator of Stoll Lands' http://www.mlnr.gov.gh/index.php/agencies/2015-06-12-08-37-10 (Accessed 25 June 2016).

Morbiwala, Z. (2015) 'The Melee Market' Rapaport Magazine http://www.diamonds.net/Magazine/Article.aspx?ArticleID=53033\&RDRIssueID=139 (Accessed June 15 2016).

Muridian, R., Verschoor, G., Bolivar, E, and G. Ochoa (2011) 'Building inclusive value chains in biotrade: A comparison of two cases from South America', pp. 266-285, in Value 
chains, inclusion and endogenous development: Contrasting theories and realities (eds. B. Helmsing and S. Vellema), London: Routledge.

Murphy, J.T. (2012). 'Global production networks, relational proximity, and the sociospatial dynamics of market internationalization in Bolivia's wood products sector', Annals of the Association of American Geographers, 102(1): 208-233.

Narayan, D. (2002) Empowerment and poverty reduction: a sourcebook, Washington D.C.: World Bank.

Nyame, F and Danso, S (2006) Socioeconomic, environmental and policy implications of alluvial diamond mining in the Birim diamondiferous field, Eastern Ghana pp. 219-226. In (eds) Hilson, G Small-Scale Mining, Rural Subsistence and Poverty in West Africa, practical Action Publishing, UK.

Nyaungwa, M. (2016) 'Ghanaian firm seeks to resuscitate Akwatia diamond mine' http://www.rough-polished.com/en/exclusive/101955.html_(Accessed June 15 2016).

Partnership Africa Canada (PAC) (2008) Diamonds and Human Security Annual Review 2008. Ottawa: Partnership Africa Canada.

Phillips, N. (2011) 'Informality, global production networks and the dynamics of "adverse incorporation"”, Global Networks, 11(3): 380-397.

Phillips, N., R. Bhaskaran, D. Nathan and C. UpendranadhRet (2011) Child labour in global production networks: poverty, vulnerability and 'adverse incorporation' in the Delhi garments sector. Working Paper No. 177. Chronic Poverty Research Centre.

Pijpers, R. (2014). 'Crops and carats: Exploring the interconnectedness of mining and agriculture in Sub-Saharan Africa', Futures 62: 32-39.

PMMC (Precious Minerals Marketing Corporation) (2016) 'Diamond Production and Marketing' http://pmmcghana.com/diamond-production-marketing/_Accessed 14 June 2016).

Porter, M. E. (1990). The Competitive Advantage of Nations. New York: Free Press.

Porter, M., E. (1985). Competitive Advantage Creating and Sustaining Superior Performance. New York: Free Press.

Raj-Reichert, G. (2013) 'Safeguarding labour in distant factories: Health and safety governance in an electronics global production network', Geoforum, 44: 23-31.

Radhuber, I.S. (2015) Extractive Processes, Global Production Networks and Inequalities. Working Paper 89, Berlin: International Research Network on Interdependent Inequalities in Latin America. 
RJC (Responsible Jewellery Council) (2014) Building Responsible Jewellery Supply

Chains Impacts Report. London: Responsible Jewellery Council.

Rowlands, J. (1997) Questioning Empowerment: Working with Women in Honduras, Oxford: Oxfam.

Selwyn, B. (2013) 'Social Upgrading and Labour in Global Production Networks: A Critique and an Alternative Conception', Competition and Change, 17(1): 75-90.

Sen, A. (1989) 'Development as capability expansion', Journal of Development Planning 19: 41-58.

Sen, A. (1999) Development as Freedom. Oxford: Oxford University Press.

Spiegel, S. (2015). 'Shifting Formalization Policies and Recentralizing Power: The Case of Zimbabwe's Artisanal Gold Mining Sector', Society \& Natural Resources 28(5): 543-558.

Tsikata, F. (1997) 'The Vicissitudes of Mineral Policy in Ghana' Resources Policy 23(1): 9-14.

Van Bockstael, (2014) 'The Persistence of Informality: Perspectives on the Future of Artisanal Mining in Liberia', Futures 62(A): 10-20.

Verbrugge, B. 2015. The Economic Logic of Persistent Informality: Artisanal and SmallScale Mining in the Southern Philippines. Development and Change 46(5): 1023-1046, p. 1024.

Werthmann, K. (2009) 'Working in a Boom-Town: Female Perspectives on Gold Mining in Burkina Faso', Resources Policy 34: 18-23.

Willis, K. (2011) Theories and practices of development, perspectives on development Oxon: Routledge.

World Bank. (1992) A Strategy for African Mining. Washington DC: World Bank. Yeung, W-C. and N. Coe (2015) 'Toward a Dynamic Theory of Global Production Networks', Economic Geography 91(1): 29-58. 